\title{
Evaluation of the systemic and therapeutic repercussions caused by drug interactions in oncology patients
}

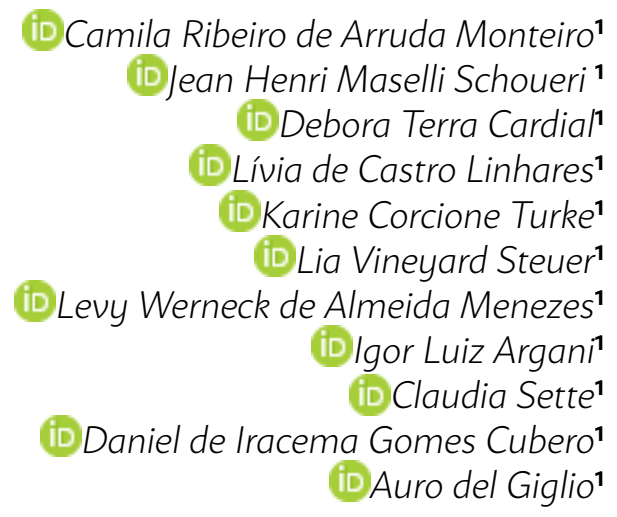

1. Faculty of Medicine of ABC, Santo André - SP, Brasil

http://dx.doi.org/10.1590/1806-9282.65.5.611

\section{SUMMARY}

INTRODUCTION: Drug interaction is an important cause of global morbidity. It is of particular importance in cancer patients since they are often in use of polypharmacy, related to interactions between the drugs and the chemotherapeutics used.

OBJECTIVE: To evaluate the drug interaction between chemotherapy and other drugs in cancer patients.

METHODS: a cross-sectional study carried out in the outpatient oncology department of a public tertiary hospital. Two hundred thirty-five patients were included, and the drugs they were using were identified. Using the MedScape and Epocrates database, we evaluated the interactions between medications and chemotherapy by defining their frequency and dividing their severity from interaction into mild, close monitoring necessity and severe.

RESULTS: 161 patients had some drug interaction. We identified 9 types of mild interactions, 23 types of interactions with close monitoring necessity, and 2 types of serious interactions. The most frequent interactions were between fluorouracil and leucovorin (32 cases) and cyclophosphamide and doxorubicin (19 cases). Serious interactions were between aspirin and pemetrexed; and leucovorin and Bactrim.

CONCLUSION: In the present study, drug interactions were frequent, including serious interactions with a potential increase in morbidity and mortality. Thus, it is necessary for oncologists to draw up a therapeutic plan considering potential interactions between prescribed chemotherapy and current medications in use by patients.

KEYWORDS: Drug interactions. Antineoplastic agents/adverse effects. Medical oncology.

\section{INTRODUCTION}

According to the World Health Organization (WHO), drug interaction is the main cause of morbid- ity and mortality in the world. ${ }^{1}$ Data indicate that, in the United States, annually, over 2 million of patients

DATE OF SUBMISSION: 14-May-2018

DATE OF ACCEPTANCE: 26-May-2018

CORRESPONDING AUTHOR: Igor Argani

Rua Lauro Gomes, 2000 - Santo Andre - São Paulo - Brasil - 09060-650

E-mail: igorargani@hotmail.com 
who are hospitalized suffer from adverse reactions to drugs, and approximately 100,000 die from it. Drug interaction, defined as an increase or reduction of the clinical effect of a given drug due to the interference of another, it is responsible for about $3 \%$ to $5 \%$ of these cases. ${ }^{2}$ This is because drug interactions can interfere in both pharmacokinetics and pharmacodynamics by inducing or inhibiting cytochrome P450, which can lead to a synergistic, additive or antagonistic effect of some drugs, thus compromising their effectiveness. $^{3}$

In general, the patients who are mostly exposed to this scenario are those who make use of polypharmacy, such as oncology patients, who need to make use of drugs not only to treat the cancer itself, but also due to the toxicity induced by the treatment and syndromes related to neoplasia, in addition to the drugs used for possible comorbidities. ${ }^{4}$

In addition, several studies have investigated drugs with the potential to interfere with chemotherapy, showing remarkable rates of drug interaction. ${ }^{5-9}$ As an example, it is known that drugs used to treat psychiatric disorders such as carbamazepine, phenytoin, phenobarbital, primidone, and valproic acid interact with chemotherapy treatments in general. ${ }^{6}$ Other drugs such as fentanyl, midazolam, captopril, and potassium chloride have also shown a high prevalence of drug interaction. ${ }^{10}$

However, the main problem lies in the use of drugs whose effects on treatment are unknown and which are often bought without restrictions by the patients, who self-medicate, usually without informing the oncologist. ${ }^{11.12}$

Similarly, van Leeuwen et al. ${ }^{7}$ predicted that over half of the patients in the use of chemotherapeutic agents present some kind of drug interaction, and a third of them suffer serious consequences. ${ }^{13}$

Due to this scenario, it is necessary to know the drugs that have the potential to interfere with the efficacy of chemotherapeutic agents, so that oncologists can draw a plan of action more accurate and individualized in order to improve the treatment offered to the patients.

\section{OBJECTIVES}

\section{General objective}

Assess drug interaction between chemotherapy and other drugs that are taken by cancer patients, with or without medical guidance.

\section{Specific objectives}

Assess the adverse effects resulting from drug interactions that might interfere with the prognosis and quality of life of patients under antineoplastic treatment.

List the drugs whose interaction is identified by this study.

Assess the effects of the drug interactions found.

\section{METHODS}

\section{Study design}

This is a cross-sectional study that analyzed patients treated by the Oncology Service linked to the FMABC (State Hospital Mário Covas, in Santo André and School Hospital Padre Anchieta, in São Bernardo do Campo). The patients were invited to participate in the study, with a previous explanation that their participation was voluntary and that their personal information would remain confidential.

We considered eligible for the study patients with age greater than or equal to 18 years, able to read and understand Portuguese and who were or were to be submitted to chemotherapy. We excluded from the study all patients younger than 18 years old, illiterate and who had not undergone chemotherapy or had no indication of a chemotherapy regimen.

After approval by the ethics committee, 235 patients were included in this study, which was based on data collection by means of an interview in which the patient answered open questions and in the evaluation of possible interactions between the drugs reported with the aid of Epocrates And MedScape applications. These free electronic applications for smartphones use, exclusively, the names of medications taken by each patient, indicating, when present, the possibility of interaction between them. The use of the applications was done by the researchers of this study, who reported the information to the participants. The information relating to the current chemotherapeutic treatment were obtained from the records of each individual patient.

After signing the Informed Consent Form - ICF, patients filled out an identification form with their clinical and demographic data, as well as a questionnaire in which they should indicate the drugs used by them: those who used without medical guidance as well as those prescribed, besides their chemotherapeutic agents.

The questionnaire contains general data of the 
patient, as staging of neoplasia, previous surgery, beginning of chemotherapy; clinical data, in which the drugs taken were disclosed, as well as the doses administered and an assessment of signs and symptoms based on the information referring to the treatment during chemotherapy; and complementary data, obtained by means of a simpler questions, aiming to evaluate all drugs used, their dosage and symptoms.

The researcher, at the time of inclusion, was responsible for clarifying the purpose of the study and assisting the subjects in answering the questionnaires.

In relation to the risks and benefits, the present study had a minimal risk in relation to the emotional

TABLE 1. SOCIODEMOGRAPHIC DATA

\begin{tabular}{|c|c|c|c|}
\hline & & $N=161$ & \\
\hline \multirow[t]{2}{*}{ Gender } & Female & 62 & $38.5 \%$ \\
\hline & Male & 99 & $61.5 \%$ \\
\hline \multirow[t]{2}{*}{ Age } & Mean & \multicolumn{2}{|c|}{61 years } \\
\hline & Interval & \multicolumn{2}{|c|}{27 to 85 years } \\
\hline \multirow[t]{3}{*}{ Marital status } & Single & 45 & $27.9 \%$ \\
\hline & Married & 100 & $62.1 \%$ \\
\hline & Widow(er) & 16 & $9.9 \%$ \\
\hline \multirow[t]{7}{*}{ Formal education } & Illiterate & 6 & $3.7 \%$ \\
\hline & $\begin{array}{l}\text { Incomplete elementary } \\
\text { school }\end{array}$ & 66 & $40.9 \%$ \\
\hline & $\begin{array}{l}\text { Complete elementary } \\
\text { school }\end{array}$ & 18 & $11.1 \%$ \\
\hline & $\begin{array}{l}\text { Incomplete secondary } \\
\text { school }\end{array}$ & 10 & $6.2 \%$ \\
\hline & $\begin{array}{l}\text { Complete secondary } \\
\text { school }\end{array}$ & 40 & $24.8 \%$ \\
\hline & $\begin{array}{l}\text { Incomplete } \\
\text { undergraduate program }\end{array}$ & 11 & $6.8 \%$ \\
\hline & $\begin{array}{l}\text { Complete undergraduate } \\
\text { program }\end{array}$ & 10 & $6.2 \%$ \\
\hline \multirow[t]{5}{*}{ Ethnicity } & White & 92 & $57.1 \%$ \\
\hline & Brown & 37 & $22.9 \%$ \\
\hline & Black & 18 & $11.1 \%$ \\
\hline & Indigenous & 8 & $4.9 \%$ \\
\hline & Others & 6 & $3.7 \%$ \\
\hline \multirow[t]{2}{*}{ Occupation } & Works & 58 & $36.0 \%$ \\
\hline & Does not work & 103 & $63.9 \%$ \\
\hline \multirow[t]{2}{*}{ Origin } & The $A B C$ region & 144 & $89.4 \%$ \\
\hline & Others & 17 & $10.5 \%$ \\
\hline \multirow{6}{*}{$\begin{array}{l}\text { Site of the } \\
\text { primary } \\
\text { neoplasia }\end{array}$} & Head and neck & 7 & $4.3 \%$ \\
\hline & Lung & 13 & $8.0 \%$ \\
\hline & Gastrointestinal tract & 58 & $36.0 \%$ \\
\hline & Urinary tract & 8 & $4.9 \%$ \\
\hline & Gynecologic & 50 & $31.0 \%$ \\
\hline & Others & 25 & $15.5 \%$ \\
\hline
\end{tabular}

context of the patient, since it caused them to reflect on questions that involve the disease, but there were no risks related to the physical health of patients. In addition, there is an indirect benefit from the implementation of future projects which, based on the collected data, can contribute to the improvement of the quality of life of these patients.

\section{RESULTS}

The present study included 235 patients. Of these, 161 had some drug interaction in accordance with the criterion of Epocrates. Their sociodemographic characteristics are presented in Table 1.

We then excluded interactions that did not involve chemotherapy drugs, dividing them remaining between "chemotherapy and chemotherapy" or "chemotherapy and non-chemotherapy. The interactions found and their frequency are shown in Table 2.

The interactions were divided into "mild", "close monitoring" and "serious", as shown in the "drug interaction Checker" of MedScape. In the chemotherapy vs. non-chemotherapy group, we found eight types of mild interactions, 14 that required close monitoring and two considered serious. Whereas in the chemotherapy vs. chemotherapy group, we found a mild interaction, nine interactions with the need for close monitoring and no serious interaction. The results can be found in Table 3 .

\section{DISCUSSION}

In oncological treatment, the concern with possible drug interactions should always be raised by the oncologist. It is worth noting that certain interactions are expected and may even be desired, especially in regard to interactions between chemotherapy drugs, between which there is a synergism of action, for example. In this context, we can cite as examples of known interactions 5-fluorouracil and leucovo$\operatorname{rin}^{14}$, or doxorubicin/cyclophosphamide followed by paclitaxel ${ }^{15}$.

Also in the context of the expected associations, the most prevalent drug interaction was between fluorouracil and leucovorin (32 cases), and it occurs during the antineoplastic treatment, with increased toxicity of the medication due to the effect of pharmacodynamic synergism. The same goes for the second most frequent drug interaction, cyclophosphamide, and doxorubicin. ${ }^{16}$ 
TABLE 2. ANALYSIS OF DEGREES OF INTERACTIONS

\begin{tabular}{|c|c|c|c|c|}
\hline \multicolumn{3}{|c|}{ Chemotherapy vs. Non-chemotherapy } & \multicolumn{2}{|l|}{ Chemotherapy vs. Chemotherapy } \\
\hline Chemotherapy & Non-chemotherapy & Frequency & Chemotherapy drugs & Frequency \\
\hline Vincristine & Prednisone & 4 & Cisplatin + Paclitaxel & 3 \\
\hline \multirow[t]{3}{*}{ Docetaxel } & Prednisone & 2 & & \\
\hline & Dexamethasone & 2 & & \\
\hline & Primidone & 1 & & \\
\hline \multirow[t]{2}{*}{ Paclitaxel } & Budesonide & 1 & & \\
\hline & Captopril & 1 & & \\
\hline \multirow[t]{2}{*}{ Glimepiride } & Prednisone & 1 & & \\
\hline & Aspirin & 1 & & \\
\hline \multirow[t]{6}{*}{ Paclitaxel } & Losartan & 6 & Fluorouracil + Leucovorin & 32 \\
\hline & Dexamethasone & 4 & Cyclophosphamide + Doxorubicin & 19 \\
\hline & Simvastatin & 3 & Paclitaxel + Doxorubicin & 7 \\
\hline & Phenytoin & 1 & Paclitaxel + Trastuzumab & 3 \\
\hline & Rosuvastatin & 1 & Irinotecan + Bevacizumab & 2 \\
\hline & Cyclosporine & 1 & Paclitaxel + Lapatinib & 1 \\
\hline \multirow[t]{2}{*}{ Cyclophosphamide } & Enoxaparin & 1 & Cisplatin + Cyclophosphamide & 1 \\
\hline & Allopurinol & 1 & Cisplatin Decarbazine & 1 \\
\hline Doxorubicin & Dexamethasone & 2 & Fluorouracil + Bevacizumab & 1 \\
\hline Docetaxel & Simvastatin & 2 & & \\
\hline Irinotecan & Dexamethasone & 2 & & \\
\hline Bortezomib & Omeprazole & 1 & & \\
\hline Etoposide & Dexamethasone & 1 & & \\
\hline Eloxatin & Zidovudine & 1 & & \\
\hline Pemetrexed & Acetylsalicylic Acid & 1 & & \\
\hline Leucovorin & Bactrim & 1 & & \\
\hline
\end{tabular}

TABLE 3. SEVERITY OF INTERACTIONS

\begin{tabular}{|c|c|c|c|}
\hline Severity of interaction & \multicolumn{2}{|c|}{$\begin{array}{l}\text { Chemotherapy vs. Non-chemotherapy } \\
\text { (Unexpected interactions) }\end{array}$} & $\begin{array}{l}\text { Chemotherapy vs. Chemo- } \\
\text { therapy }\end{array}$ \\
\hline \multirow[t]{3}{*}{ Mild } & Vincristine & Prednisone & \multirow[t]{3}{*}{ Cisplatin + Paclitaxel } \\
\hline & Docetaxel & $\begin{array}{l}\text { Prednisone; Dexamethasone } \\
\text { Primidone }\end{array}$ & \\
\hline & Paclitaxel & Budesonide; Captopril & \\
\hline \multirow{9}{*}{ Close monitoring } & Glimepiride & Prednisone; Aspirin & Fluorouracil + Leucovorin \\
\hline & Paclitaxel & $\begin{array}{l}\text { Losartan; Dexamethasone } \\
\text { Simvastatin; Phenytoin } \\
\text { Rosuvastatin; Cyclosporine }\end{array}$ & $\begin{array}{l}\text { Cyclophosphamide + } \\
\text { Doxorubicin }\end{array}$ \\
\hline & Cyclophosphamide & Enoxaparin; Allopurinol & Paclitaxel + Trastuzumab \\
\hline & Doxorubicin & Dexamethasone & Irinotecan + Bevacizumab \\
\hline & Docetaxel & Simvastatin & Paclitaxel + Lapatinib \\
\hline & Irinotecan & Dexamethasone & \\
\hline & Bortezomib & Omeprazole & \\
\hline & Etoposide & Dexamethasone & \\
\hline & Eloxatin & Zidovudine & \\
\hline \multirow[t]{2}{*}{ Severe } & Pemetrexed & Acetylsalicylic acid & \\
\hline & Leucovorin & Bactrim & \\
\hline
\end{tabular}


The third most frequent interaction, paclitaxel and doxorubicin, even though it was already expected to have increased toxicity related to their combined use bringing an improved oncologic prognosis ${ }^{16}$, it should be mentioned that the interaction between them includes increased levels of doxorubicin, considering the decrease of renal clearance of creatinine generated by paclitaxel..$^{16}$ Thus, it is observed that associations of chemotherapeutic agents may present, concomitantly, intentional drug interactions associated to harmful interactions.

Among the serious interactions, the one between aspirin (acetylsalicylic acid; ASA) and pemetrexed is noteworthy. Pemetrexed is a chemotherapeutic agent indicated for the treatment of non-small cell lung cancer, ${ }^{17}$ while acetylsalicylic acid is used as secondary prophylaxis of new cardiovascular events ${ }^{18}$. Considering the frequency of concomitance of these comorbidities, both in part secondary to smoking ${ }^{19}$, there is the possibility of a same patient receiving the association of pemetrexed and ASA. Despite this, these medications should not be associated, since aspirin increases the levels of pemetrexed due to decreased renal excretion of the chemotherapeutic agent. It is worth mentioning that this association should be undertaken with caution in patients with normal renal function (creatinine clearance $>80 \mathrm{ml} /$ min) and avoided in patients with preserved renal function, because, due to this factor, aspirin can raise the levels of pemetrexed and cause adverse events. ${ }^{20}$

To avoid such interaction, one possibility would be to replace acetylsalicylic acid by another antiplatelet agent that also causes reduction of cardiovascular risk during the period of oncological treatment, such as clopidogrel21, which presents no drug interactions with the pemetrexed ${ }^{16}$.

Another serious interaction was found between leucovorin and Bactrim (trimethoprim and sulfamethoxazole). Leucovorin corresponds to a drug used, among other reasons, in association with fluorouracil, for adjuvant chemotherapeutic treatment of colorectal cancer and for recovery in patients treated with high doses of methotrexate ${ }^{22.23}$. Bactrim, in turn, corresponds to an antibiotic often used for infectious prophylaxis in oncologic patients who are immunosuppressed during the chemotherapy treatment ${ }^{24}$. Thus, there is the possibility of the same patient using both drugs simultaneously, and leucovorin decreases the effect of trimethoprim due to a mechanism of pharmacodynamic antagonism. ${ }^{16}$
To avoid the interaction between leucovorin and Bactrim, the antibiotic can be replaced for another that is effective and does not interact with the leucovorin. ${ }^{24.25}$

As discussed, it is observed that drugs used for oncologic therapy are not an exception in the context of drug interactions. In addition, these drugs have important cytotoxic effects and feature many pharmacokinetic and pharmacodynamic variations among patients. As noted, the use of combinations and the number of drugs involved in the treatment increases the likelihood of such interactions. ${ }^{26}$

Thus, the presence of drug interactions among cancer patients is noteworthy. In this scenario, in addition to the associations made intentionally by oncologists with the purpose of increasing the effectiveness of the treatment, there are also those that occur without the supervision of these professionals, arising mainly from drugs taken without informing the medical team.

Furthermore, oncology patients are particularly prone to polypharmacy ${ }^{27-29}$, making use of several drugs simultaneously. Thus, in addition to the greater risk of drug interactions, more than one interaction can be present in the same patient, increasing the possibility of unwanted effects and worsen prognosis $^{27-29}$.

An important example of multiple interactions in oncologic patients corresponds to that of chemotherapeutic agents, such as paclitaxel associated with simvastatin and losartan, drugs widely prescribed in older patients ${ }^{30.31}$. Although beneficial in isolation, paclitaxel presents drug interaction with both other drugs, with the need for close monitoring ${ }^{16}$. Simvastatin and losartan lead to unwanted increases in the levels of paclitaxel, increasing its toxicity; paclitaxel brings an increased risk of myopathy related to simvastatin. ${ }^{16}$ Multiple interactions such as this should be carefully assessed by the oncologist, especially in patients in use of multiple drugs simultaneously.

The serious interactions found were between aspirin and pemetrexed, and leucovorin and Bactrim. Although the present study has found only individual cases of the concomitant use of drugs with serious drug interaction, this can probably be explained by the limitation of the small number of patients included, since the high prevalence of the use of these medications ${ }^{18.24}$ indicates that the frequency of unwanted interactions is possibly even higher. Thus, it reinforces the idea that physicians should be alert 
to the possible effects from such interactions and how they vary according to each patient, which can result in a worse prognosis for patients in neoplastic treatment.

\section{CONCLUSION}

Drug interactions were frequent in oncologic patients. Although the majority of interactions was related to the synergistic effect already expected between chemotherapy drugs, there were unexpected serious interactions and interactions with the need of close monitoring The main interactions found were the severe increase of chemotherapy toxicity due to the worsening of renal function, which may increase the mortality related to the treatment; and the reduction of the effect of antibiotic medication, related to an increased risk of bacterial infection and, consequently, an increase in mortality.

Thus, it is necessary that oncologists create a therapy plan considering possible drug interactions between the chemotherapy prescribed and other drugs used by the patients in order to ensure a better oncologic prognosis.

\section{RESUMO}

INTRODUÇÃO: Interação medicamentosa é uma importante causa de morbidade mundial. Apresenta especial importância em pacientes oncológicos, pois esses frequentemente estão em uso de polifarmácia, podendo haver interações entre os medicamentos e os quimioterápicos utilizados.

OBJETIVO: Avaliar a interação medicamentosa entre a quimioterapia e outros medicamentos em pacientes oncológicos.

MÉTODOs: Estudo transversal realizado em serviço ambulatorial de oncologia de um hospital público terciário. Foram incluídos 235 pacientes, identificando-se quais medicamentos eram utilizados por eles. Por meio do auxílio do banco de dados do MedScape e Epocrates, avaliaram-se as interações entre as medicações e os quimioterápicos, definindo sua frequência e dividindo sua gravidade da interação em leve, monitorização próxima e grave.

RESULTADOS: Do total estudado, 161 pacientes apresentavam alguma interação medicamentosa, sendo nove tipos de interações leves, 23 tipos de interações com necessidade de monitorização próxima e dois tipos de interações graves. As interações mais frequentes foram entre fluoracil e leucovorin (32 casos) e ciclofosfamida e doxorrubicina (19 casos). As interações sérias foram entre aspirina e pemetrexed; e leucovorim e bactrim.

CONCLUSÃO: No presente trabalho, interações medicamentosas foram frequentes, incluindo interações graves com potencial aumento de morbimortalidade. Assim, faz-se necessário que oncologistas tracem um plano terapêutico levando em consideração as possíveis interações medicamentosas entre a quimioterapia prescrita e demais medicações em uso pelos pacientes.

PALAVRAS-CHAVE: Interações medicamentosas. Antineoplásicos/efeitos adversos. Oncologia.

\section{REFERENCES}

1. McCance-Katz EF, Sullivan LE, Nallani S. Drug interactions of clinical importance among the opioids, methadone, and buprenorphine, and other frequently prescribed medications: a review. Am J Addict. 2010;19(1):4-16.

2. Mealey KL, Fidel J. P-glycoprotein mediated drug interactions in animals and humans whit cancer. J Vet Itern Med. 2015;29(1):1-6.

3. van Leeuwen RW, Brundel DH, Neef C, van Gelder T, Mathijssen DM Burger FG. Prevalence of potential drug-drug interactions in a cancer patients treated with oral anticancer drugs. Br J Cancer. 2013;108(5):1071-8.

4. Riechelmann RP, Del Giglio A. Drug interactions in oncology: how common are they? Ann Oncol. 2009;20(12):1907-12.

5. Popa MA, Wallace KJ, Brunello A, Extermann M, Balducci L. Potential drug interaction and chemotoxicity in older patients with cancer receiving chemotherapy. | Geriatr Oncol. 2014;5(3):307-14.

6. Yap KY, Chui WK, Chan A. Drug interactions between chemotherapeutic regimens and antiepileptics. Clin Ther. 2008;30(8):1385-407.

7. van Leeuwen RW, Swart EL, Boven E, Boom FA, Schuitenmaker MG, Hugtenburg JG. Potential drug interactions in cancer therapy: a prevalence study using an advanced screening method. Ann Oncol. 2011;22(10):2334-41

8. Scripture CD, Figg WD. Drug interactions in cancer therapy. Nat Rev Cancer. 2006;6(7):546-58.
9. Chan A, Tan SH, Wong CM, Yap KY, Ko Y. Clinically significant drug-drug interactions between oral anticancer agents and nonanticancer agents: a Delphi survey of oncology pharmacists. Clin Ther. 2009;31(Pt 2):2379-86.

10. Reis AM, Cassiani SH. Prevalence of potential drug interactions in patients in an intensive care unit of a university hospital in Brazil. Clinics (Sao Paulo). 2011;66(1):9-15.

11. Riechelmann RP, Tannock IF, Wang L, Saad ED, Taback NA, Krzyzanowska $M K$, et al. Potential drug interactions and duplicate prescriptions among cancer patients. J Natl Cancer Inst. 2007;99(8):592-600.

12. Riechelmann RP, Moreira F, Smaletz O, Saad ED. Potential for drug interactions in hospitalized cancer patients. Cancer Chemother Pharmacol. 2005;56(3):286-90.

13. Gaui MFD. Interações medicamentosas no paciente oncológico. Onco\& 2010;19-23.

14. Arkenau HT, Bermann A, Rettig K, Strohmeyer G, Porschen R; Arbeitsgemeinschaft Gastrointestinale Onkologie. 5-Fluorouracil plus leucovorin is an effective adjuvant chemotherapy in curatively resected stage III colon cancer: long-term follow-up results of the adjCCA-01 trial. Ann Oncol. 2003;14(3):395-9.

15. Andrade DAP, Zucca-Matthes G, Vieira RAC, Andrade CTAE, Costa AM, Monteiro AJC, et al. Quimioterapia neoadjuvante e resposta patológica: coorte retrospectiva. Einstein (São Paulo). 2013;11(4):446-50. 
16. Reference.medscape.com. (2015). Multi-Drug Interaction Checker. [online] [cited 3 May 2017]. Available from http://reference.medscape.com/ drug-interactionchecker

17. Fuld AD, Dragnev KH, Rigas JR. Pemetrexed in advanced non-small-cell lung cancer. Expert Opin Pharmacother. 2010;11(8):1387-402.

18. Godley RW, Hernandez-Vila E. Aspirin for primary and secondary prevention of cardiovascular disease. Texas Heart Inst J. 2016;43(4):318-9.

19. Higenbottam T, Shipley MJ, Rose G. Cigarettes, lung cancer, and coronary heart disease: the effects of inhalation and tar yield. J Epidemiol Community Health. 1982;36(2):113-7.

20. Agência Europeia de Medicamentos. [cited 8 August 2017]. Available from: http://ec.europa.eu/health/documents/communityregister/2017/20170216137129/anx_137129_pt.pdf

21. Pilgrim T, Windecker $S$. Antiplatelet therapy for secondary prevention of coronary artery disease. Heart. 2014;100(22):1750-6.

22. Ragnhammar $P$, Hafström L, Nygren $P$, Glimelius B; SBU-group. Swedish Council of Technology Assessment in Health Care. A systematic overview of chemotherapy effects in colorectal cancer. Acta Oncol. 2001;40(23):282-308.

23. Marley AR, Nan H. Epidemiology of colorectal cancer. Int J Mol Epidemiol Genet. 2016;7(3):105-14.
24. Yoshida M, Ohno R. Antimicrobial prophylaxis in febrile neutropenia. Clin Infect Dis. 2004;39(Suppl 1):S65-7.

25. Kern WV, Marchetti O, Drgona L, Akan H, Aoun M, Akova M, et al. Oral antibiotics for fever in low-risk neutropenic patients with cancer: a double-blind, randomized, multicenter trial comparing single daily moxifloxacin with twice daily ciprofloxacin plus amoxicillin/clavulanic acid combination therapy - EORTC infectious diseases group trial XV. J Clin Oncol. 2013;31(9):1149-56.

26. Beijnen $\mathrm{JH}$, Schellens $\mathrm{JH}$. Drug interactions in oncology. Lancet Oncol. 2004:5(8):489-96.

27. LeBlanc TW, McNeil MJ, Kamal AH, Currow DC, Abernethy AP. Polypharmacy in patients with advanced cancer and the role of medication discontinuation. Lancet Oncol. 2015;16(7):e333-41.

28. Sokol KC, Knudsen JF, Li MM. Polypharmacy in older oncology patients and the need for an interdisciplinary approach to side-effect management. J Clin Pharm Ther. 2007;32(2):169-75.

29. Lees J, Chan A. Polypharmacy in elderly patients with cancer: clinical implications and management. Lancet Oncol. 2011;12(13):1249-57.

30. Xu F, Mao C, Hu Y, Rui C, Xu Z, Zhang L. Cardiovascular effects of losartan and its relevant clinical application. Curr Med Chem. 2009;16(29):3841-57.

31. Robinson JG. Simvastatin: present and future perspectives. Expert Opin Pharmacother. 2007:8(13):2159-27. 